\title{
THE PERCENTUAL DISTRIBUTION AND FREQUENCY OF OCCURRENCE OF DIATOMS IN BOTTOM SEDIMENTS IN THE AIRISTO AND PAIMIONLAHTI REGIONS IN SOUTHWEST FINLAND
}

\author{
AARRE HEINO
}

\begin{abstract}
HEINO, A., 1987. The percentual distribution and frequency of occurrence of diatoms in bottom sediments in the Airisto and Paimionlahti regions in southwest Finland. Bull. Geol. Soc. Finland 59, Part 2, 155-170.

This study deals with the occurrence and percentual distribution of diatoms in the Airisto and Paimionlahti regions in southwest Finland. The formation of sediments in the area has been influenced by land uplift and the resultant phases in the evolution of the Baltic Sea. These have affected the freshwater and brackishwater content of the Baltic. Simultaneous with deposition of the sediments, there has been a change from open water to the present kaleidoscopic character of the archipelago.

The diatom flora of the sediments proved to be very varied. Freshwater sediments are characterised by large individual numbers of a few species, Melosira islandica and Stephanodiscus astraea, while brackish-water sediments have a more even distribution of many species. The effect of redeposition can be seen clearly in the diatom flora of the sediments. There was a clear correlation between the numbers of certain diatoms but, on the whole, the correlations were small if the large numbers of species are borne in mind. The saltier Mastogloia phase could be clearly distinguished in many cores. The diagrams show that the species have considerably multiplied in variety in more recent sediments. Coscinodiscus granii, Coscinodiscus asteromphalus and Achnanthes taeniata, which predominate in young sediments, have achieved their present abundance only in the most recent sediments. This has taken place at the expence of Epithemia species, for example.
\end{abstract}

Key words: diatom flora, marine sediments, fresh-water environment, brackish-water environment, Baltic Sea Stages, Holocene, Airisto, Paimionlahti, Turku, Finland.

Aarre Heino: Department of Geography, University of Turku, 20500 Turku.

\section{Introduction}

The sea areas that lie off Turku have been widely studied at the University of Turku. Facilities for research improved considerably when the University's Archipelago Research Institute was set up at Seili on the island of Nauvo in 1964. The most intensive research has been in biology, geography and geology. The study of diatoms is connected with all three of these and has conse- quently taken on the nature of interdisciplinary research. It is mainly biologists who have studied the present diatom flora in the region (e.g. Rautiainen and Ravanko 1972; Ravanko and Tynni 1974; Ravanko 1977). Sediment diatoms, on the other hand, have been the focus of research by geographers and geologists (e.g. Heino 1973; Glückert 1976, 1977; Alhonen et al. 1984). Sediment research has shown that diatoms can prove as useful tool in distinguishing the sedi- 
ments of the different stages in the development of the Baltic Sea from each other (e.g. Heino 1973, 1979; Eronen 1974).

This study concentrates on examining the occurrence of and relationship between different diatoms found in sediments of different ages in the study area. Similarities and differences in occurrence are determined by means of correlation analysis, for example. Since freshwater and brackish-water species differ considerably from each other, Ancylus Lake and Litorina Sea species have been studied separately in the correlation analyses.

The area from which samples were taken is situated in the southwest of Finland in the vicinity of the city of Turku (approx. 170000 inh.). The study area forms part of the easternmost part of the archipelago of southwest Finland just off the mainland. The area is characterised by large islands with narrow sounds running between them and the mainland to form a complex network of narrow and shallow waterways. There are two largish areas of open water in the study area - Airisto and Paimionlahti (Fig. 1), from which the bulk of the samples were taken. Both these stretches of water are situated in old fracture zones of the bedrock. The depth of water in them is even more than $100 \mathrm{~m}$, which is unusual in this area of inner archipelago (Heino 1973). Airisto, in particular, is characterised by lively maritime traffic since the fairways to Turku and the port of Naantali north of Turku pass through it. In Paimionlahti there is no such traffic by large vessels. Because of isostatic uplift of the earth's crust the relationships between land and sea have been subject to constant change. The quality of the water has varied between fresh and brackish. The salt content of the present day is about $6-7 \%$.

\section{Evolution of the Baltic in southwest Finland}

The melting of the ice sheet in Scandinavia was followed by isostatic uplift of the land in the areas that had been covered by ice. As the ice melted, it also caused a global eustatic rise in sea level. In the Baltic area these two events took place simultaneously and as a result a situation was created which was characterised by successive sea and lake stages dependent on whether the Baltic was an arm of the Atlantic or not. The present view of the evolution of the Baltic is the result of prolonged and diverse work by many scholars (in Finland Sauramo 1958; Donner 1965; Alhonen 1979; Eronen 1974; Glückert 1976; etc.). In general it is possible to distinguish a series of phases in the development of the Baltic subsequent to the melting of the ice (e.g. Alhonen 1979). The first of these was the Baltic ice lake phase, when the southernmost edge of the ice extended as far south as the Salpausselkä ridges until, in about 8213 B.C. there was a rapid drop in sea level and it became the Yoldia Sea. Because of the large amount of meltwater the salt content of this sea was probably very small, at least along the Finnish coast (Alhonen 1971). The glacier covering southwest Finland melted during the Yoldia period between 7900 and 7800 B.C. (Glückert 1976). The oldest sediments in the study area date back to this time. Around the year 7200 B.C. there was again a transgression stage, which led to the Ancylus Lake. The sediments of this large lake formed thick dams on top of the Yoldia sediments. The transformation of the Yoldia Sea into the freshwater Ancylus Lake which followed probably took place gradually and there is no clear boundary discernible either by eye or with an echo sounder (Heino 1973) such as the stratum of coarser-grained material much poorer in its orcanic content that marks the boundary between Ancylus and Litorina sediments (cf. also Alhonen et al. 1978).

The penetration of salt seawater from the Atlantic into the Baltic at the end of the Ancylus period began to raise the salt content of the sea along the west coast of Finland in about 54005200 B.C. (Glückert 1976). Somewhat earlier, in about 6000 B.C. there are signs in the diatom flora of the Baltic of a small increase in salt con- 


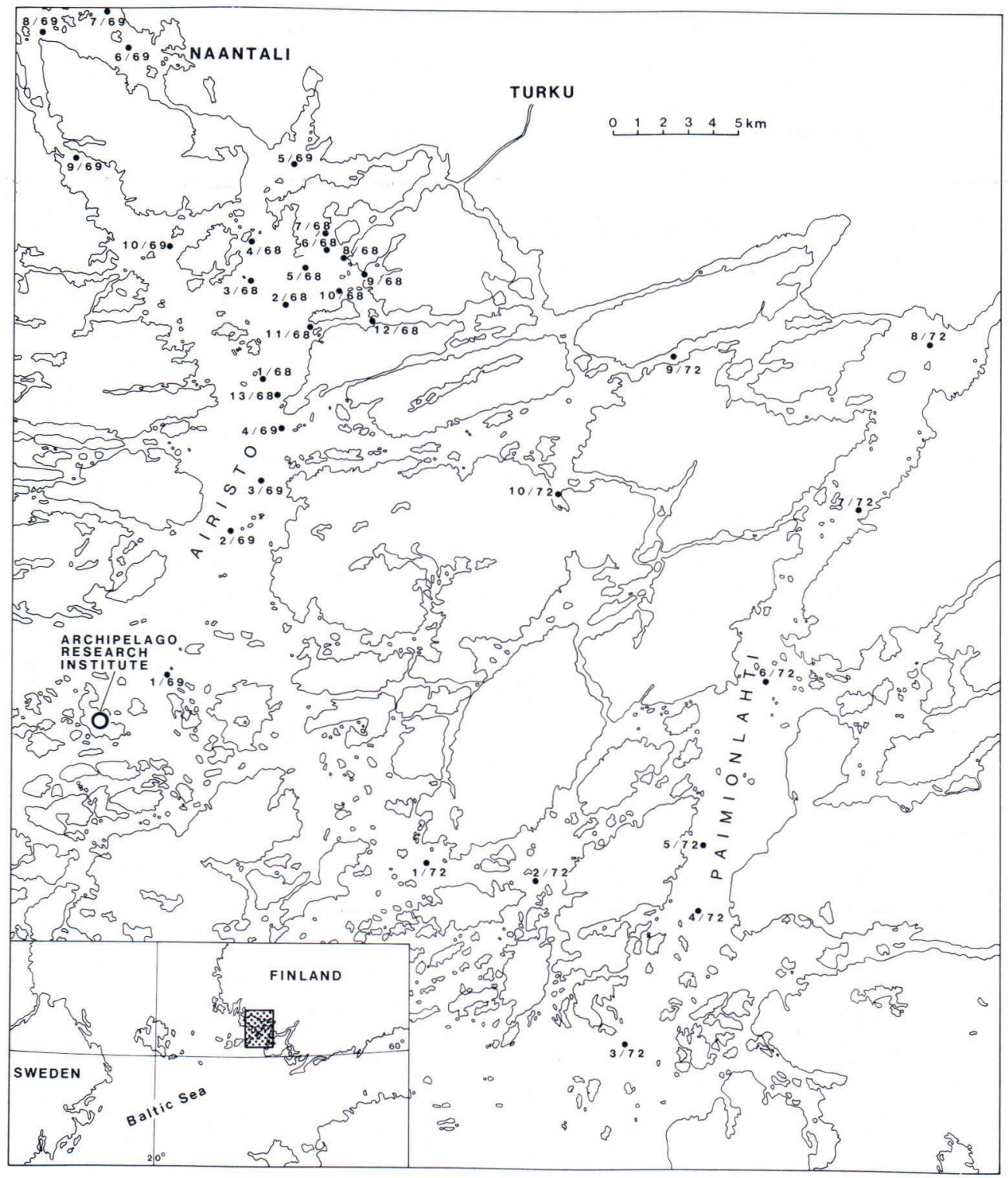

Fig. 1. Study area and location of the cores.

tent. This can be seen mainly in the form of a change in the composition of the diatom flora in the littoral zone (Alhonen 1979). This Mastogloia phase has been dated to $8070 \pm 250$ B.P. in southwest Finland (Eronen 1974). Alhonen et al. (1978) established a date of $7740 \pm 170$ B.C. for sediments lying immediately above the boundary. In the case the point in the core from which the sample was taken explains the different dating.

In the early stages of the Litorina phase, which followed the Ancylus Lake, the sea level in southwest Finland was $50 \mathrm{~m}$ higher than what it is today (Glückert 1976). Consequently, in the 
Turku area, for example, only the peaks of the highest hillocks were visible above the surface of the water as small skerries and islands. For diatoms just as for other Baltic organisms the transition to brackish water was most significant. This can be observed in the changes that took place in the species of diatoms. The boundary between Ancylus and Litorina sediments is abrupt, and the sediments on both sides of the boundary differ in type from each other and are easily recognisable (Heino 1973).

The Litorina Sea phase still continues in the Baltic. Especially in its most recent stage the changes in the open sea along the coast of southwest Finland that have resulted in a labyrinth characterised by shallow, narrow straits has markedly affected conditions in the marine environment. This has in turn wrought changes in the diatom flora of the sediments. The process that has reduced the depth of the sea has also increased bottom and shore erosion, which has caused the wearing away, transport and redeposition of old diatom-containing sediments. In many places near the shore or in narrow sounds the waves and currents have entirely prevented the deposition of young sediments. Freshwater diatoms are carried to the area by rivers but their proportion in the diatom flora of the sediments is small. The degree of land uplift in the area is now of the order of $0.5 \mathrm{~mm} / \mathrm{a}$. Since the ice sheet melted, the land surface has risen more than $100 \mathrm{~m}$ in relation to sea level. This indicates that uplift has gradually slowed as some 9800-9900 years have elapsed since the melting of the glaciers that covered southwest Finland (Glückert 1976).

\section{Research materials and analyses}

The diatom materials used in this study were collected over the years 1968, 1969 and 1972 . Cores were taken from 33 different points (Fig. 1) with the aid of a $3 \mathrm{~m}$ Kullenberg core sampler (cf. Heino 1973, 1979).
The cores were divided into $2 \mathrm{~cm}$-long sections and diatom determinations were made from 461 such sections. The samples were treated with hydrogen peroxide, after which the portion of the sample containing diatoms was separated from the other material by means of decantation. In order to determine the percentual distribution of the diatoms $100-500$ diatoms were counted in each sample. A minimum of at least 100 diatoms was taken from 427 samples, and this constituted the final material for the study. Each sample was examined as a whole in order to decide the frequency of occurrence for the entire material. When the percentages of the different diatom species were calculated, each species of diatom found in the sample was given the minimum value of 1 per cent. This meant the cumulative quantity of diatoms in almost all the samples totalled more than 100 per cent.

The total amount of organic material and the water content in the sediments were determined by means of the Walkley-Black method (Morgans 1956). The results were then given as a percentage of dry weight of each sample. Some of these data and also the diatom diagrams of some of the materials have been published earlier (Heino 1973, 1979; Alhonen et al. 1984).

\section{Frequency of occurrence and percentual distribution of diatoms in sediments}

After the diatoms had been determined and the quantities of organic matter calculated, the samples were divided into two groups (cf. Heino 1973). Of the 461 samples analysed 217 were classed as Ancylus or older types and 244 as Litorina types. The sediments of the Mastogloia phase were classified in general as being of Ancylus type. It was not an altogether easy task to determine the boundary in the case of certain samples from the actual transition zone even though the boundary between the two groups was usually quite sharp. Distinguishing Yoldia sediments from Ancylus sediments proved very dif- 
ficult. The explanation for this lay partly in the fact that there were few Yoldia sediments in the material studied. Moreover, the density of diatoms in the Yoldia Sea is very small (Ignatius and Tynni 1978), and the proportion of freshwater forms, largely the same as those most common during the Ancylus phase, is considerable (Alhonen 1971, Ignatius and Tynni 1978). On the basis of the above criteria it would appear that the bottom sections of samples 2/69, 9/69 and 9/72 constituted Yoldia sediments. In these only a few diatoms were found and among them were not only large-lake types such as Melosira islandica spp. helvetica and Stephanodiscus astraea but also brackish-water species generally regarded as Yoldia Sea types: Actinocyclus ehrenbergi, Thalassiosira baltica, Grammatophora oceanica, Melosira moniliformis and Coscinodiscus lacustris. The quantity of organic matter in these sediments was $1-2$ per cent whereas in Ancylus sediments it was usually $2-4$ per cent. The samples in question were not included in the statistical analysis of the diatom flora since the individual number of diatoms was insufficient for calculations.

According to the frequency of the diatom species in the samples, the most commonly encountered species proved to be Melosira islandica (spp. helvetica) and Stephanodiscus astraea, which were undoubtedly the most abundant in Ancylus sediments. Furthermore, because of redeposition they also occur in large quantities in younger Litorina sediments. Also present in large numbers were Epithemia turgida + var. westermanni, the normal occurrence of which embraces both types of sediments.

Rather small individual numbers but high frequencies were characteristic of Litorina sediment diatoms. However, there were 28 species exceeding the 1-per cent level in Litorina sediment while in Ancylus samples there were only 9. The only diatom with a frequency exceeding 90 per cent in Ancylus samples was Melosira islandica. In Litorina sediments, on the other hand, eight species was present in more han 90 per cent of samples: Melosira islandica, Epithemia turgida, Diploneis smithii, Grammatophora oceanica, Coscinodiscus lacustris, Nitzschia punctata, Synedra tabulata and Melosira moniliformis. This shows that there is much greater variety of brackish-water forms than of freshwater-forms. The diatom flora in Litorina sediments increased in variety in the upper sections of the samples as the predominance of Epithemia turgida + var. westermanni decreased (Figs. 2-5).

More than 90 per cent of all diatoms in this study consisted of only 40 species having the proportion of at least 0.5 per cent (Table 1). Just two of the most abundant species, Melosira islandica and Stephanodiscus astraea, accounted for almost a third of individual numbers. This is explained by the fact that they are clearly the most abundant species in Ancylus sediments and, because of resedimentation, are also abundant in Litorina sediments. More than half of the individual numbers were made up of five species: these were, in addition to the two just mentioned, Epithemia turgida + var. westermanni, Melosira italica and Coscinodiscus lacustris.

According to the percentual distribution of the diatom species in different types of samples, in Litorina sediments, especially younger ones, no species clearly predominated. In the oldest Litorina sediments and Mastogloia sediments Epithemia turgida + var. westermanni approached in some cases almost as high figures as those for Melosira islandica and Stephanodiscus astraea in Ancylus sediments.

\section{Correlations between frequency of occurrence of diatoms}

Linear correlation coefficients were calculated for the percentages for the 47 species with the highest frequency of occurrence. They were calculated both for the entire material used in the study and for the Litorina and Ancylus samples separately. The aim of this was to determine how individual statistical methods intended for use 


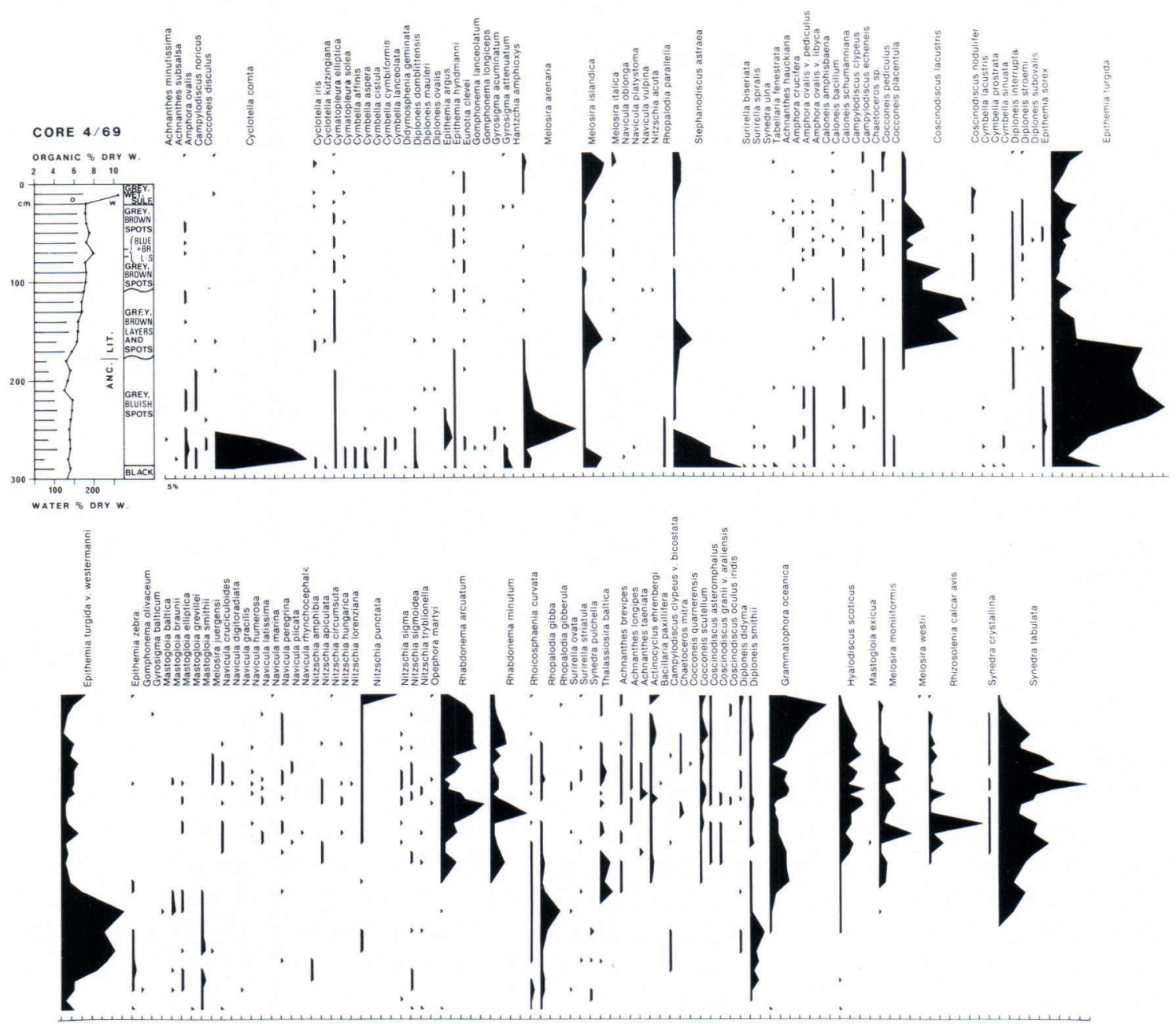

Fig. 2. Litho- and biostratigraphy of the core $4 / 69$.

with large bodies of material can be applied to establishing a similar occurrence of diatoms in different ecological environments. Nine cores giving a total of 173 samples were selected so that there were both Litorina and Ancylus samples in each 87 of the former and 86 of the latter. This choice was made because the boundary between the Ancylus and Litorina phases was the only clearly discernible change in the sediments studied, and also because the interesting Mastogloia phase was probably represented in the cores selected for this operation. The cores used for the correlation calculations were 6/68, 4/69, 5/69, $6 / 69,8 / 69,2 / 72,4 / 72,5 / 72$ and 6/72 (Fig. 1). 

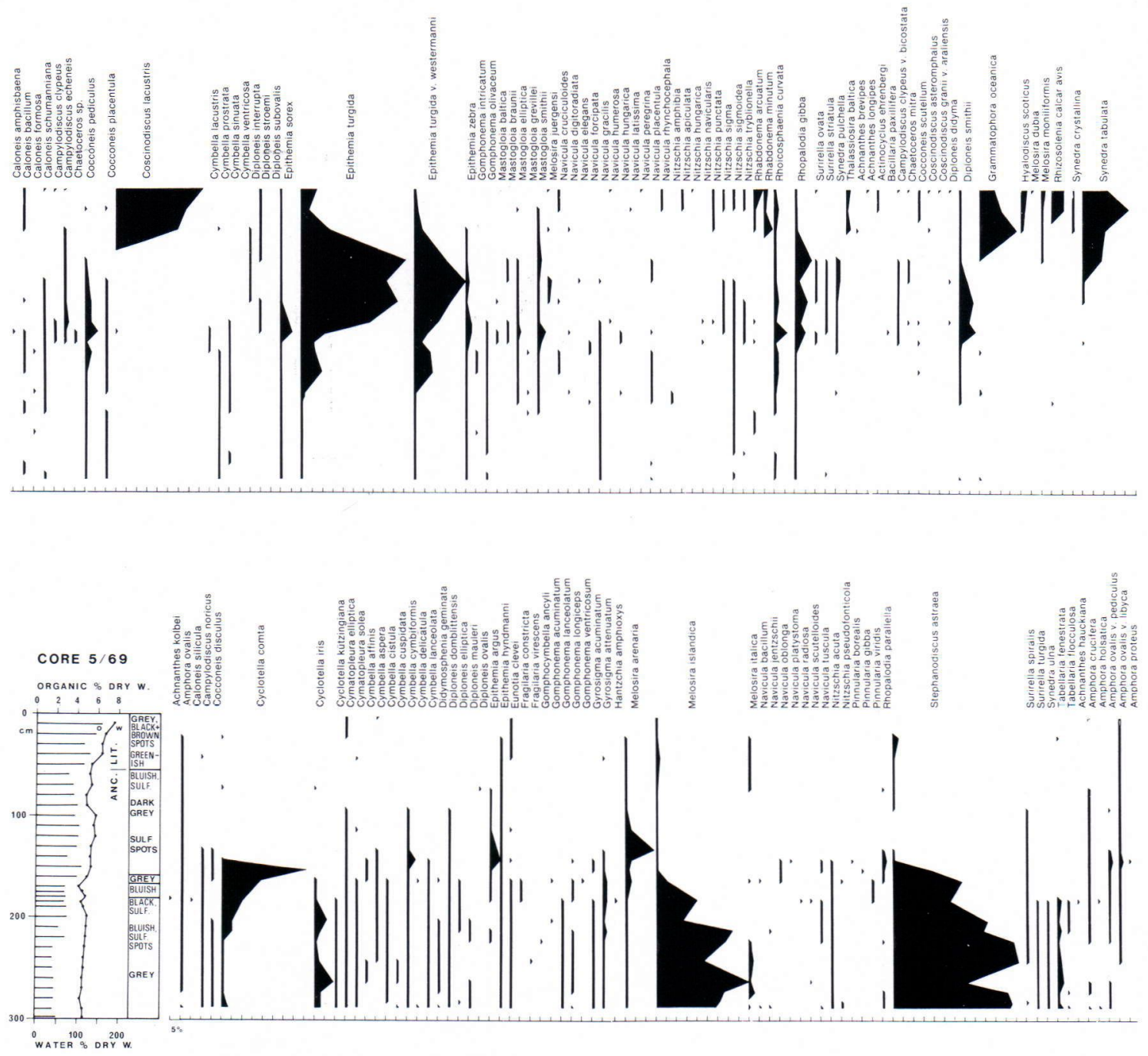

Fig. 3. Litho- and biostratigraphy of the core $5 / 69$.

Among the most frequently encountered diatoms which had to be omitted from the calculations for technical reasons were Cymatopleura solea, Cymatopleura elliptica and Nitzschia tryblionella. This was because their percentage in all the samples included in the correlation calculations was the same, i.e. 1. Diatoms from purely Ancylus or Litorina samples were omitted from the correlation calculations if the total number of individual diatoms in the samples was less than 10 . The correlation between the distribution percentages of the diatoms was, in fact, small. In the case of the samples taken from Litorina sediments correlation coefficients were calculated for 

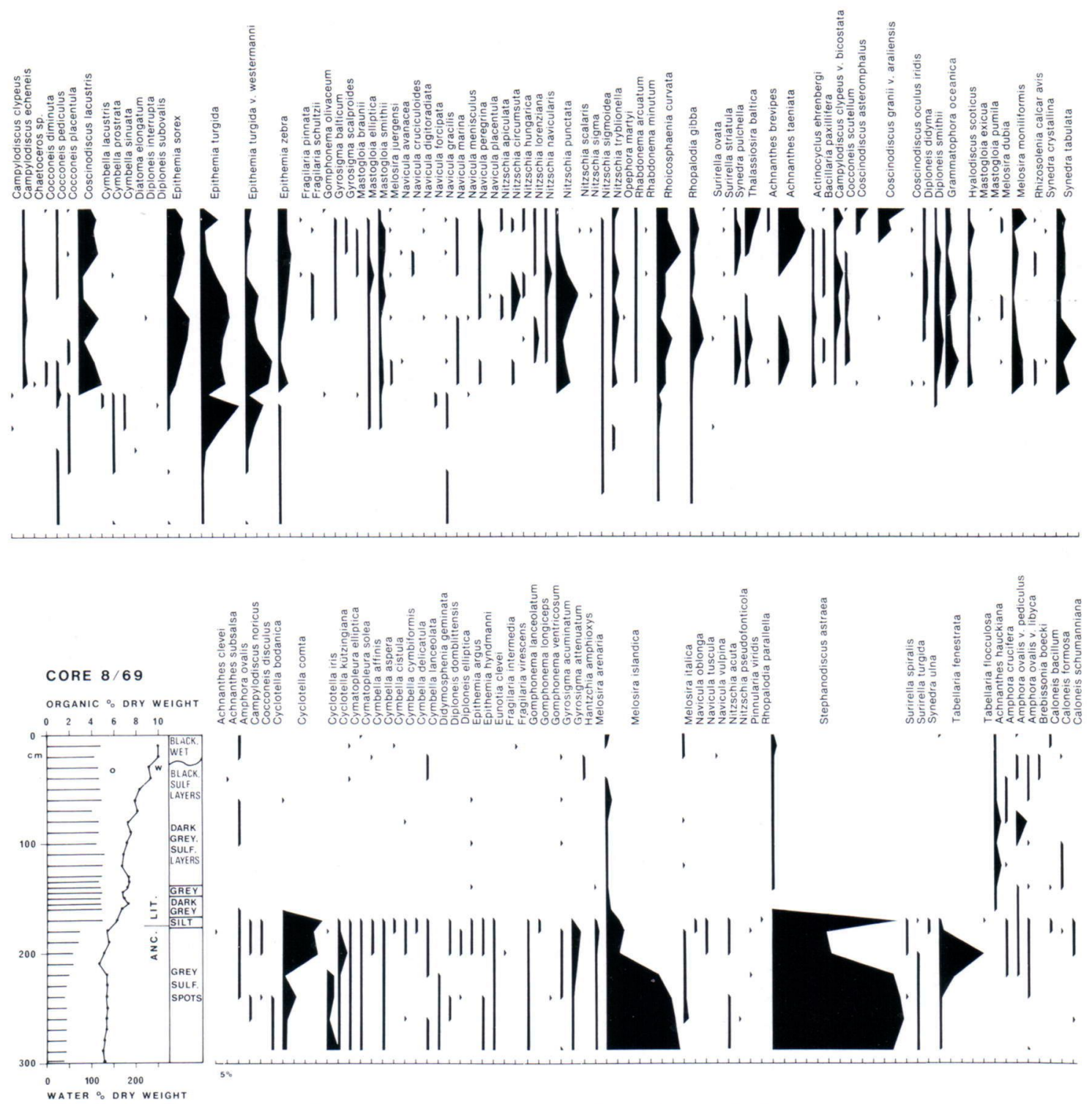

Fig. 4. Litho- and biostratigraphy of the core $8 / 69$.

38 diatoms altogether, resulting in 703 correlating pairs, and in the case of Ancylus samples for 24 diatoms, resulting in 276 correlations. A correlation coefficient better than $>0.49$ was achieved for 21 calculations between 17 different diatoms for the Litorina samples and for 21 calculations between 24 diatoms for the Ancylus samples. In both cases the correlation was found to obtain principally within a fairly homogenous group of diatoms (Figs. 6 and 7). It is interesting to note that in both types of sediments much the same diatoms were included in the group Epithemia sorex, Epithemia zebra, Mastogloia smithii and Rhopalodia gibba. These are species 

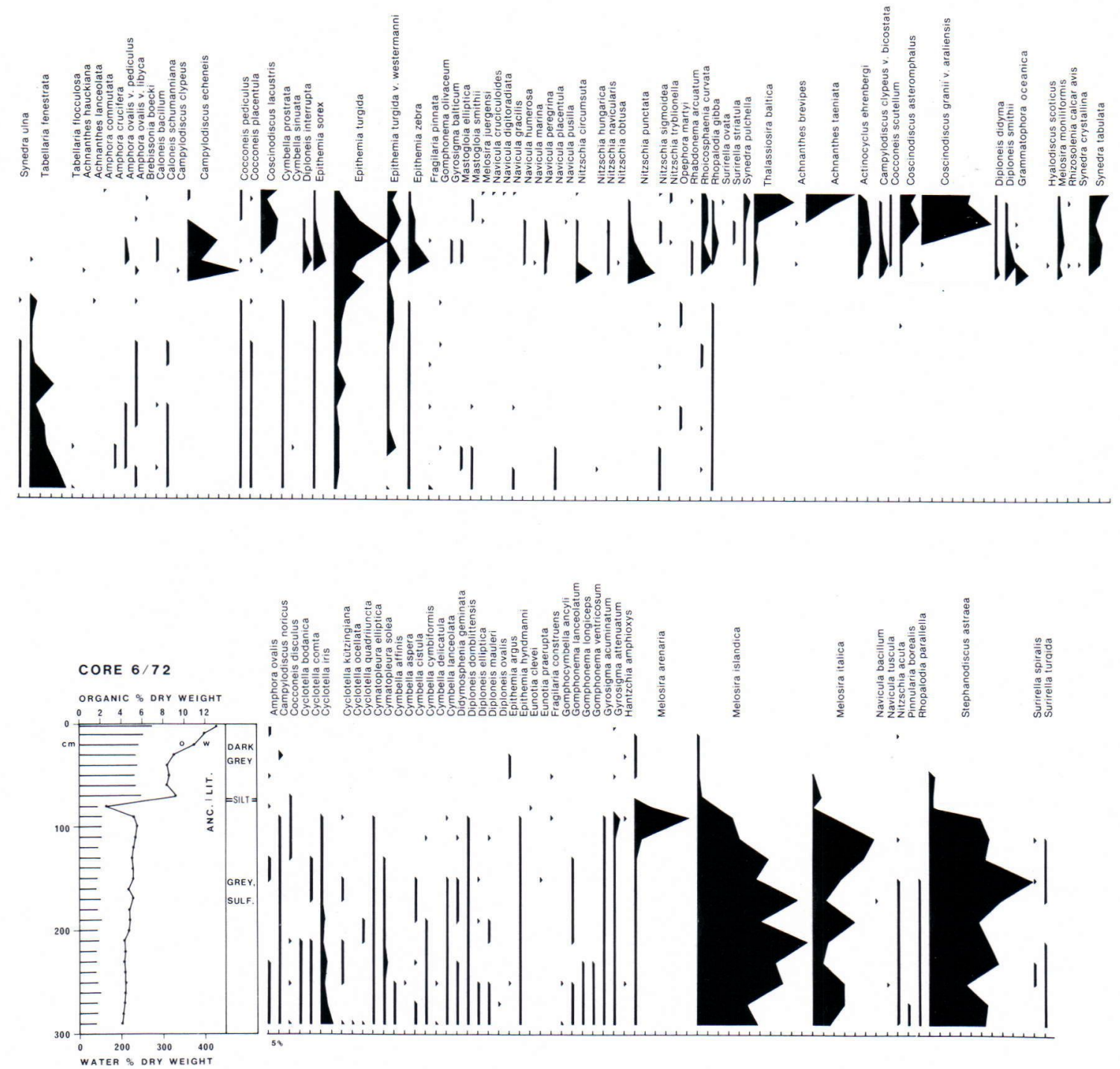

Fig. 5. Litho- and biostratigraphy of the core $6 / 72$.

found in both freshwater and brackish water habitats; moreover they are also species regarded as characteristic of the Mastogloia phase. For the entire material, there were only 31 coefficients, between 28 different diatoms, with a value better than $>0.49$ among the 1081 coefficients calculated. The choice of the used borderline value was subjective; it is impossible to establish any absolute border of this kind between good and poor correlation. The coefficient used was clearly statistically significant in all the calculations below the 0.1 per cent risk level.

The calculation of the linear correlation alone did not, of course, give the best possible results 
Table 1. Percentual proportion and frequency of the most common diatom species $(n=461)$.

\begin{tabular}{|c|c|c|}
\hline & $\%$ & fr. \\
\hline Melosira islandica & 21.9 & 94.6 \\
\hline Stephanodiscus astraea & 10.8 & 84.4 \\
\hline Epithemia turgida & 6.6 & 87.6 \\
\hline Melosira italica & 5.0 & 62.0 \\
\hline Epithemia turgida var. westermanni & 3.9 & 83.1 \\
\hline Coscinodiscus lacustris & 3.8 & 52.5 \\
\hline Synedra tabulata & 3.5 & 51.6 \\
\hline Grammatophora oceanica & 2.5 & 52.8 \\
\hline Cocconeis scutellum & 1.9 & 49.5 \\
\hline Achnanthes taeniata & 1.8 & 31.2 \\
\hline Tabellaria fenestrata & 1.7 & 49.9 \\
\hline Actinocyclus ehrenbergi & 1.6 & 50.1 \\
\hline Thalassiosira baltica & 1.6 & 42.5 \\
\hline Melosira moniliformis & 1.5 & 51.4 \\
\hline Epithemia sorex & 1.4 & 60.1 \\
\hline Rhabdonema arcuatum & 1.4 & 49.0 \\
\hline Rhoicosphaenia curvata & 1.4 & 61.0 \\
\hline Hyalodiscus scoticus & 1.3 & 41.1 \\
\hline Coscinodiscus granii & 1.2 & 18.0 \\
\hline Rhopalodia gibba & 1.2 & 66.4 \\
\hline Epithemia zebra & 1.1 & 63.3 \\
\hline Melosira arenaria & 1.1 & 54.4 \\
\hline Diploneis smithii & 1.0 & 55.7 \\
\hline Rhizosolenia calcar-avis & 1.0 & 34.1 \\
\hline Campylodiscus clypeys var. bicostata & 0.9 & 35.8 \\
\hline Campylodiscus echeneis & 0.9 & 46.0 \\
\hline Cocconeis pediculus & 0.9 & 66.6 \\
\hline Nitzschia punctata & 0.9 & 52.5 \\
\hline Synedra pulchella & 0.9 & 30.2 \\
\hline Cyclotella comta & 0.8 & 27.1 \\
\hline Cymatopleura solea & 0.8 & 31.9 \\
\hline Coscinodiscus asteromphalus & 0.7 & 35.4 \\
\hline Cyclotella iris & 0.6 & 39.5 \\
\hline Cymatopleura elliptica & 0.6 & 52.9 \\
\hline Diploneis didyma & 0.6 & 45.6 \\
\hline Mastogloia smithii & 0.6 & 32.3 \\
\hline Nitzschia tryblionella & 0.6 & 40.6 \\
\hline Amphora ovalis & 0.5 & 45.8 \\
\hline Gyrosigma attenuatum & 0.5 & 49.7 \\
\hline \multirow[t]{2}{*}{ Nitzschia sigmoidea } & 0.5 & 46.9 \\
\hline & 91.5 & \\
\hline
\end{tabular}

nor was it intended that the study should be comprehensive in this respect. Nonetheless, this part of the study is perhaps justified as an example of the possibility of applying statistical methods to diatom research. By developing suitable forms of analysis, e.g. cluster analysis, it might be possible to formulate different regional models.

\section{The Mastogloia phase}

Studies of diatoms in the sediments of the Baltic have often reported observations in the Baltic Sea of a so-called Mastogloia phase characterised by a low salt content, just before the end of the Ancylus Lake period (e.g. Eronen 1974; Alhonen et al. 1978). The identification of this period in the evolution of the Baltic is based on the occurrence of certain diatom species that prefer brackish water but which are nevertheless also found in fresh water in the upper levels of Ancylus sediments just before the beginning of the Litorina phase. Such species encountered in this study include Mastogloia elliptica, Mastogloia braunii, Mastogloia smithii, Diploneis smithii, Navicula peregrina, Synedra pulchella and Epithemia turgida + var. westermanni (cf. Figs. 2-5). In addition to these species other conspicuous types especially in this study were Rhopalodia gibba, Rhoicosphaenia curvata and Epithemia zebra. In diatom diagrams 4/69 and 5/69 Mastogloia species constitute a rather clearly delimited group just below the boundary between Ancylus and Litorina. The lower section of both these diagrams consists of clearly distinguishable Ancylus-type diatom species. The situation as far as the diagrams for other cores are concerner is more unclear. In core $8 / 69$ attention is drawn to the paucity of Epithemia species and the large number of Tabellaria fenestrata at what is assumed to be the Mastogloia phase. This is in clear contradistinction to the situation in cores 4/69 and 5/69. On the other hand, the same kinds of species are to be found in core $6 / 72$, but here they are found in the bottom sections of the core. In this diagram however, Mastogloia-type species should be found above the Ancylus/Litorina boundary. But the large quantity of organic matter together with the large percentage of Litorina species in the sediments perhaps indicates the existence of the Litorina phase proper. In these sediments, however, a small increase in Epithemia species together with a decline in Melosira islandica, Melosira italica and Stephanodiscus 


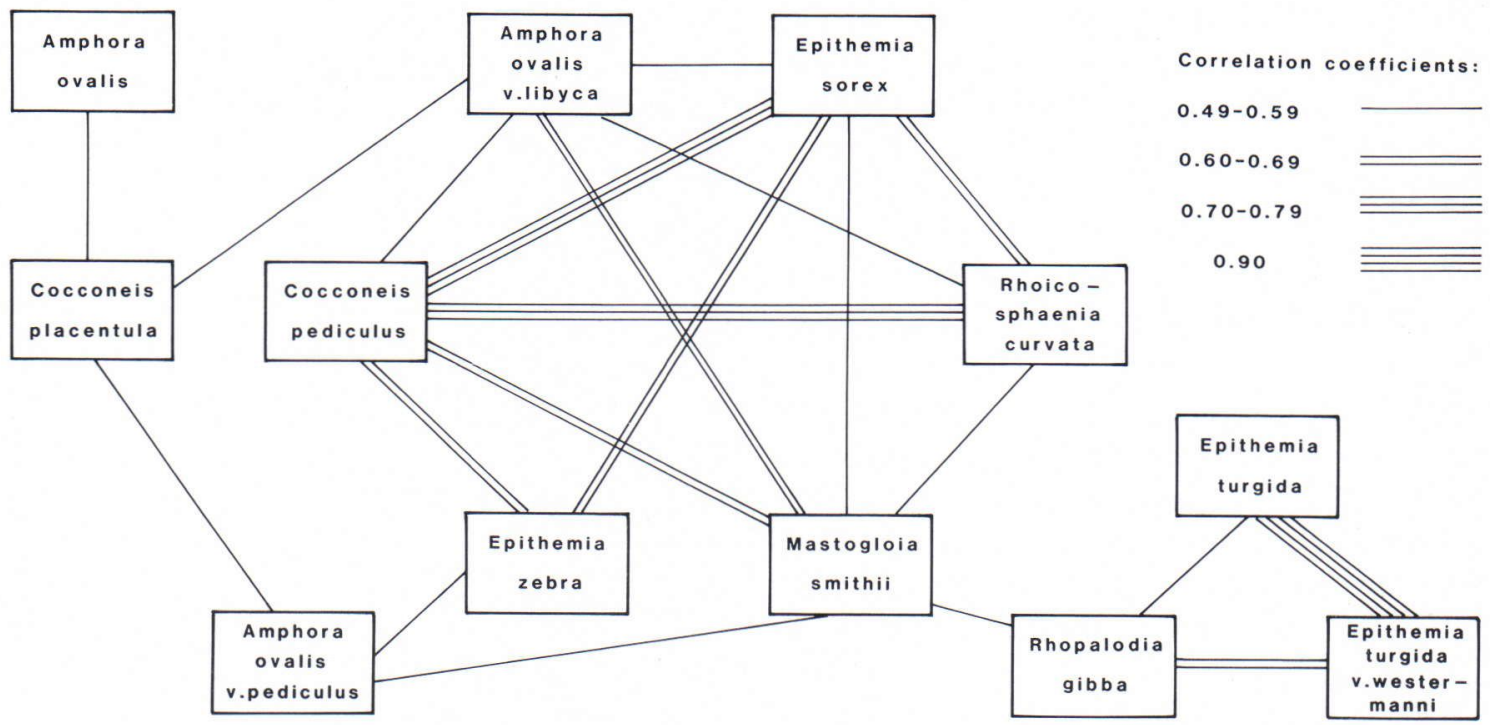

Fig. 6. Prominent group of correlations among the number of diatoms in Ancylus sediments.

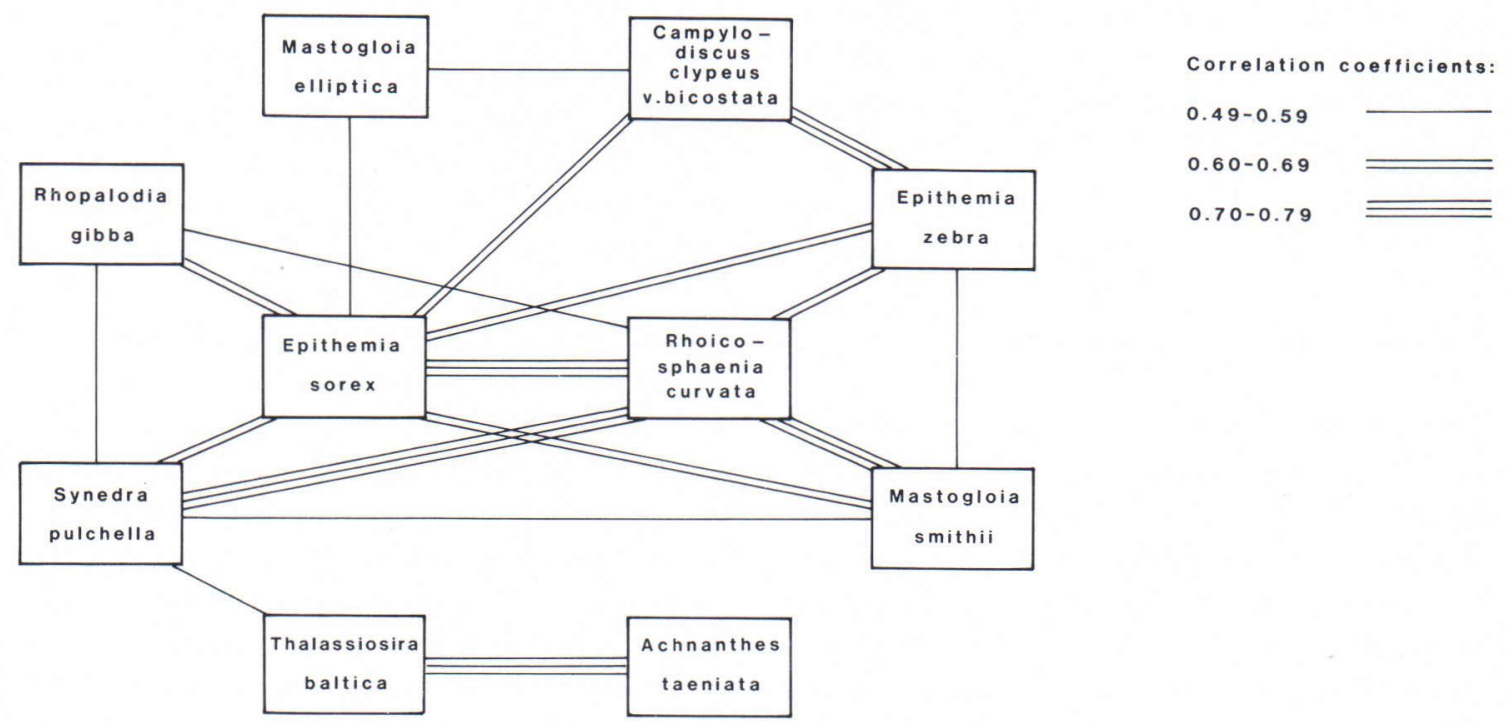

Fig. 7. Prominent group of correlations among the number of diatoms in Litorina sediments. 
astraea can be seen somewhat above the Ancylus/ Litorina boundary. This may possibly be indicative of a weak Mastogloia phase in this position. In that case the characteristic Mastogloia species would obviously be seen only in cores 4/69 and $5 / 69$ of this study. This interpretation would seem to be supported by earlier reports of cores 6/69 and 5/72 (Alhonen et al. 1984), in the first of which the Mastogloia phase is clearly visible as a short stage right on the boundary between the Ancylus and Litorina phases. Immediately above the Mastogloia-phase species it is possible to see a short-lived increase in large-lake species before the actual onset of the Litorina species proper. The diatoms at whose expense the brackish-water species of the Mastogloia phase increase are mainly Melosira islandica and Stephanodiscus astraea.

This study therefore supports earlier studies on the distinction of a Mastogloia phase in southwest Finland. The species concerned could not be clearly observed in all the cores. The reasons for this might be the short period of time covered by the phase and perhaps, even more so, regional features dependent on the proximity of the shore and the great distance to the straits between the Baltic and the North Sea. The organic content of sediments from the Mastogloia phase is slightly higher than that of Ancylus sediments. However, the differences are so small, that it is impossible to distinguish the sediments on the basis of this.

\section{Diatoms in younger sediments}

The percentages of the most common diatoms in the topmost samples $(n=27)$ of the cores were calculated separately. There were altogether 26 species with percentages amounting to at least 1 per cent of the total material (Table 2). The fact that Melosira islandica was the most frequently encountered species indicates the importance of redeposition in the region, as does also Stephanodiscus astraea in fourth place. The most com-
Table 2. Percentual proportion and frequency of the most common diatom species in the uppermost samples of the cores $(\mathrm{n}=27)$.

\begin{tabular}{lcc}
\hline & $\%$ & fr. \\
\hline Melosira islandica & 8.6 & 24 \\
Achnanthes taeniata & 8.4 & 20 \\
Coscinodiscus granii & 8.1 & 21 \\
Stephanodiscus astraea & 6.6 & 24 \\
Epithemia turgida & 6.5 & 27 \\
Coscinodiscus lacustris & 5.3 & 21 \\
Thalassiosira baltica & 4.7 & 19 \\
Epithemia turgida var. westermanni & 4.3 & 26 \\
Synedra tabulata & 3.7 & 25 \\
Nitzschia punctata & 3.6 & 22 \\
Actinocyclus ehrenbergi & 3.6 & 23 \\
Coscinodiscus asteromphalus & 3.5 & 21 \\
Melosira moniliformis & 2.6 & 21 \\
Cocconeis scutellum & 2.6 & 23 \\
Grammatophora marina & 2.2 & 22 \\
Campylodiscus echeneis & 2.2 & 21 \\
Melosira italica & 1.9 & 19 \\
Rhoicosphaenia curvata & 1.6 & 22 \\
Epithemia sorex & 1.3 & 25 \\
Epithemia zebra & 1.2 & 23 \\
Rhopalodia gibba & 1.2 & 21 \\
Rhabdonema arcuatum & 1.1 & 20 \\
Cocconeis pediculus & 1.0 & 21 \\
Melosira arenaria & 1.0 & 17 \\
Diploneis didyma & 1.0 & 23 \\
Nitzschia tryblionella & 1.0 & 18 \\
\hline & 88.8 & \\
\hline & & \\
& & \\
& &
\end{tabular}

mon brackish-water diatoms were Achnanthes taeniata and Coscinodiscus granii (var. araliensis), both of which are to be found in abundance everywhere in the youngest sediments (diatom diagrams, Figs. 2-5). These two species and Coscinodiscus asteromphalus, which is very reminiscent of Coscinodiscus granii in appearance, are extremely characteristic of young sediments in the study area. The author has found them in great abundance among the present species found in Airisto. Because on their large size the Coscinodiscus diatoms referred to give the impression that they predominate entirely in most samples, especially since the bulk of other species consist often of Achnanthes taeniata, which are small in size. Because it has a thin shell Achnanthes taeniata is not very well preserved 
in sediments. This may explain why it is abundant in young sediments. A feature worth noting is that no Licmophora species, which also have thin shells, were found in the sediment samples even though Ravanko and Tynni (1974) and the author, for example, have found such species among those now inhabiting Airisto.

Although Mölder and Tynni (1968) note that Coscinodiscus asteromphalus is a common diatom in the Litorina Sea, and Alhonen (1979) dates the Coscinodiscus species as belonging to the same phase in the evolution of the Baltic, it seems that their proportion of the total species flora in the study area is larger than usual. The same is true of Achnanthes taeniata although Mölder and Tynni (1972) and Ignatius and Tynni (1978), for example, report it as common in both Litorina and post-Litorina sediments. The increase in the number of these species has been largerly at the expense of Epithemia species (cf. Figs. 2-5).

\section{Conclusions and comparison}

The results of diatom studies are usually given in the form of separate cores and not as frequency and mean values for regions, as has been done in this study in many cases. For this reason comparison of characteristic species found in the area with the species commonly found in other areas can only be done on the basis of individual diatom diagrams.

The percentage of Yoldia species was small in the material used in this study so that such species are not found in any of the diatom diagrams nor in the tables. Since the most common species of this period are Melosira islandica ssp. helvetica and Stephanodiscus astraea (Eronen 1974; Alhonen 1979), which are also typical Ancylus species, and because the density of diatoms in Yoldia sediments is extremely small, it is difficult to distinguish Yoldia and Ancylus sediments from each other on the basis of the diatom flora. Using the low diatom density and certain brackish-water species it is nonetheless possible to distinguish Yoldia sediments, as was shown in this study. Sediment that was in many respects similar was found, in the lower section of sample $9 / 68$, for example. However, the abundance of Ancylus forms and the fact that the site from which the sample was taken lies near a steeply dipping shore make it reasonable to assume that in fact it is a question of strong redeposition during the Ancylus phase under the influence of littoral forces.

Melosira islandica (ssp. helvetica), a typical large-lake diatom (Mölder and Tynni 1967), is clearly the most common diatom (more than 40 per cent) in Ancylus sediments. The percentage of this particular species rose to more than 90 per cent in individual samples, particularly in the oldest Ancylus sediments. That this species had a percentage of more than 5 per cent in Litorina sediments is due to the erosion of old Ancylus strata and redeposition. Melosira islandica correlates best with Melosira italica. In frequency of occurrence Melosira islandica was the most common diatom, being present in more than 90 per cent of all the samples analysed during the study.

Stephanodiscus astraea with its 20-per cent share is the second most common diatom in Ancylus sediments. In Litorina sediments, however, it accounts for even 3 per cent, which is due to redeposition. There was a quantitatively positive correlation with most other large-lake diatoms, indicating the ecological similarity of these species. Such species included Gyrosigma attenuatum, Cyclotella iris and Melosira italica.

Among large-lake species Tabellaria fenestrata (3.3\% in Ancylus sediments) accounted for the largest proportion of individual diatoms in certain samples (Fig. 4). In quantity it did not, however, correlate with any other species. Besides the species above, only Cyclotella comta $(1.6 \%)$, Melosira arenaria $(1.3 \%)$ and Cymatopleura elliptica $(1 \%)$ reached the one-per-cent level in Ancylus sediments. Of these Melosira arenaria also exceeded one per cent in Litorina sediments. 
The diatom flora of the Ancylus Lake corresponded rather well in this study with the picture given in the literature. The percentage of Melosira arenaria is, however, rather smaller than is usually portrayed (Alhonen et al. 1978; Ignatius and Tynni 1978). The reason for this may be that, according to Eronen (1974), Melosira arenaria is found in abundance in sandy sediments. A further explanation is perhaps the great depth of water in the study area during the Ancylus phase. This favours pelagic species at the expense of benthos and epiphytic species. Eronen (1974) also classifies Opephora martyi and Diploneis mauleri as typical Ancylus species. The numbers of these two species were extremely small in this study, so much so that Opephora martyi was encountered more frequently in Litorina sediments. Only one individual of Caloneis latiuscula, which is regarded as belonging to Ancylus species by Ignatius and Tynni (1978), was found in this study.

When the Mastogloia phase began at the end of the Ancylus phase brackish-water species began to appear in the eastern parts of the Baltic Sea even though the amount of meltwater was large owing to the proximity to the ice sheet. The increase in the salt content of the water must therefore have been smaller than in the parts of the Baltic nearer the Atlantic. The proportion of Mastogloia species proper as described in the literature (e.g. Eronen 1974; Alhonen 1979) is relatively small in the material of this study, which is characterised by an abundance of Epithemia species, with Epithemia turgida + var. westermanni, as the most typical. Rhopalodia gibba, which was commonly found among Mastogloia species in this study, is hardly mentioned at all elsewhere in the literature.

Epithemia turgida and Epithemia turgida var. westermanni constitute a morphological series from the longest to the shortest forms and require a similar ecological environment (Tynni 1980). For this reason it is not so easy to distinguish them from each other. On the other hand, it is perhaps not necessary, either. Therefore their occurrence is sometimes treated jointly in this study. Epi- themia turgida + var. westermanni together formed the third most common species in the whole material. Among Litorina diatoms they took first place and among Ancylus sediment species they were third after Melosira islandica and Stephanodiscus astraea. They were particularly characteristic of the Mastogloia phase. Ecologically the epiphytic Epithemia turgida is well adapted to both Ancylus and Litorina conditions (Tynni 1980). This is clearly observable in the diatom diagrams (Fig. 2-5). The maximum occurrence of Epithemia turgida + var. westermanni was, in addition to the Mastogloia phase, in which it was often the most common species, also often the oldest Litorina sediments. In frequency of occurrence it took second place in the whole material after Melosira idlandica, and in Litorina sediments it was found in practically every sample.

The Litorina Sea was characterised by a much larger variety of diatom species than the Ancylus Lake phase. As a whole the most common species was Epithemia turgida + var. westermanni which, as in the Mastogloia phase, appears as an epiphyte in shallow water near the shore. The socalled Clypeus flora, which is typical very close to the shore (Eronen 1974; Alhonen 1979; Glückert 1976, 1977) appear in most of the studied material but only the Epithemia species referred to be abundantly represented. Other relatively abundant diatoms in the same group included Rhoicosphaenia curvata, Campylodiscus echeneis, Diploneis smithii, Nitzschia tryblionella, Mastogloia smithii and Navicula peregrina. Synedra tabulata, which was common in this study, is not mentioned at all by the above authors but is referred to by Ignatius and Tynni (1978). On the other hand, such species as Amphora mexicana, Anomoenois sphaerophora and Surirella capronii are absent from this study. Typical Litorina species mentioned by Eronen (1974) and Alhonen (1979) among pelagic types were also encountered in this study. These included Coscinodiscus spp., especially Coscinodiscus lacustris and the less frequently mentioned Coscinodiscus 
asteromphalus and Coscinodiscus granii var. araliensis, Thalassiosira baltica, Actinocyclus ehrenbergi, Achnanthes taeniata, Grammatophora oceanica, Rhabdonema arcuatum and Rhoicosphaenia curvata. In addition to these, commonly occurring species of this group found in this study but less frequently mentioned by other authors were Cocconeis scutellum, Rhizosolenia calcaravis, Rhopalodia gibba, Cocconeis pediculus and Diploneis didyma.

Coscinodiscus lacustris, which was the second most common diatom in Litorina sediments after Epithemia turgida + var. westermanni with a percentage of 7 per cent, did not correlate in number with any other diatom species. Ecologically it is classified as a freshwater or slightly brackish-water species (Mölder and Tynni 1968) but in the materials of this study its occurrence was restricted almost entirely to Litorina sediments.

Synedra tabulata with a share of 6.5 per cent was the third most common diatom in Litorina sediments. Although it is a brackish-water epiphytic type (Mölder and Tynni 1970), its occur-

\section{References}

Alhonen, P., 1971. The stages of the Baltic Sea as indicated by the diatom stratigraphy. Acta Bot. Fennica $92.18 \mathrm{p}$.

-, 1979. The quaternary history of the Baltic, Finland. In Gudelis, V. and Königsson, L.-K. (Eds.) The Quaternary History of the Baltic, 101-113. Acta Univ. Ups., Symp. Univ. Ups., Annum Quingetesimum Celebrantis, 1. Uppsala.

—; Eronen, M.; Núñez, M.; Salomaa, R. \& Uusinoka, R., 1978. A contribution to Holocene shore displacement and environmental development in Vantaa, South Finland: The stratigraphy of Lake Lammaslampi. Bull. Geol. Soc. Finland 50, 69-79.

- \& Mansikkaniemi, H., 1978. Observations of sedimentation of diatoms in some Finnish rivers. Fennia 156, pp. $1-9$.

—; Heino, A. \& Tynni, R., 1984. Über Vorkommen und Bedeutung von Terpsinoe americana (Bail.) Ralfs in den Ablagerungen des Litorinameeres. Bull. Geol. Soc. Finland $56,117-133$.

Donner, J. J., 1965. The Quaternary of Finland. In Ranta- rence correlates rather well with the pelagic species Hyalodiscus scoticus, which is similar in its saltwater requirements. The proportion of the latter in Litorina sediments was 2.4 per cent.

Grammatophora oceanica (4.7\%), Cocconeis scutellum (3.5\%) Achnanthes taeniata (3.3) and Thalassiosira baltica $(3.0 \%)$ each acounted for $3-5$ per cent of Litorina species. Of these only the last two correlate with each other. The high frequency of occurrence of Grammatophora oceanica, which was present in more than 90 per cent of Litorina samples, shows that it is relatively evenly distributed throughout all the sediments in the study area. On the other hand, the relatively low frequency of Achnanthes taeniata, 58 per cent, is explained by the fact that this species is concentrated to young Litorina sediments.

Acknowledgments. The author wishes to thank Prof. Pentti Alhonen who read the manuscript, Mrs Leena Kiiskilä, who drew the diagrams and figures and Mr Christopher Grapes, who translated the text.

ma, K. (ed.) Quaternary Interscience Publ., New YorkLondon-Sydney, pp. 199-272.

Eronen, M., 1974. The history of the Litorina Sea and associated Holocene events. Soc. Sci. Fennica, Comm. Phys. Math. 44 (4), 79-195.

Glückert, G., 1976. Post-Glacial shore-level displacement of the Baltic in SW Finland. Ann. Acad. Sci. Fennicae A. III. $118,1-92$.

—, 1977. Itämeren rannansiirtymisestä Turussa ja sen lähiympäristössä. Abstract: Post-Glacial shore-level displacement of the Baltic at Turku, SW-Finland. Publications of the Department of Quaternary geology, Univ. Turku 21, $36 \mathrm{pp}$.

Heino, A., 1973. Bottom deposits and sedimentation in northern Airisto in Southwestern Finland. Bull. Geol. Soc. Finland $45,131-142$.

- 1979. The pattern of organic content and some heavy metals in the bottom sediments of Airisto, SW-Finland. Turun yliopiston maantieteen laitoksen julkaisuja Publicationes Instituti Geographi Universitatis Turkuensis $89,1-52$.

Ignatius, H.\& Tynni, R., 1978. Itämeren vaiheet ja piilevä- 
tutkimus. Baltic Sea stages and diatom analysis. Turun yliopiston maaperägeologian osaston julkaisuja - Publications of the Department of Quaternary Geology, University of Turku $36,1-26$.

Morgans, J. F. C., 1956. Notes on the analysis of shallow water soft substrata. J. Anim. Ecol. 25, 367-387.

Mölder, K. \& Tynni, R., 1967. Über Finnlands rezente und subfossile Diatomeen I. C. R. Soc. Geol. Finlande 39, 199-217.

— \& Tynni, R., 1968. Über Finnlands rezente und subfossile Diatomeen II. Bull. Geol. Soc. Finland 40, 151-170.

— \& Tynni, R., 1969. Über Finnlands rezente und subfossile Diatomeen III. Bull. Geol. Soc. Finland 41, 235-251.

- \& Tynni, R., 1970. Über Finnlands rezente und subfossile Diatomeen IV. Bull. Geol. Soc. Finland 42, 129-144.

- \& Tynni, R., 1971. Über Finnlands rezente und subfossile Diatomeen V. Bull. Geol. Soc. Finland 43, 203-220.

— \& Tynni, R., 1972. Über Finnlands rezente und subfossile Diatomeen VI. Bull. Geol. Soc. Finland 44, 141-149.

— \& Tynni, R., 1973. Über Finnlands rezente und subfossile Diatomeen VII. Bull. Geol. Soc. Finland 45, 159-179.

Rautiainen, H. \& Ravanko, O., 1972. The Epiphytic Diatom Flora of the Benthic Macrophyte Communities on Rocky
Shores in the Southwestern Archipelago of Finland, Seili Islands. Nova Hedwigia XXIII, 827-842.

Ravanko, O., 1977. Ahdinparralla kasvavista piilevistä. Luonnon Tutkija $81,51-54$.

Ravanko, O.\& Tynni, R., 1974. On some species of the genus Licmophora in Finland. Memoranda Soc. Fauna Flora Fennica 50, 5-14.

Sauramo, M., 1958. Die Geschichte der Ostsee. Ann. Acad. Scient. Fennicae, A III, 51, 522 pp.

Simonsen, R., 1962. Untersuchungen zur Systematik und Ökologie der Bodendiatomeen der westlichen Ostsee. Internationale Revue der Gesamten Hydrobiologie, Systematische Beihefte I.

Tynni, R., 1974. Über Finnlands rezente und subfossile Diatomeen VIII. Geol. Surv. Finland, Bull. 274, 55 pp.

- , 1976. Über Finnlands rezente und subfossile Diatomeen IX. Geol. Surv. Finland, Bull. 284, 37 pp.

-, 1978. Über Finnlands rezente und subfossile Diatomeen X. Geol. Surv. Finland, Bull. 296, 55 pp.

-, 1980. Über Finnlands rezente und subfossile Diatomeen XI. Geol. Surv. Finland, Bull. 312, 93 pp.

Manuscript received March 10, 1987. 